\title{
A network of the steppe and forest steppe along the Prut and Lower Danube rivers during the $6^{\text {th }}$ millennium BC
}

\author{
Agathe Reingruber \\ Institute of Prehistoric Archaeology, Freie Universität Berlin, Berlin, DE \\ areingruber@zedat.fu-berlin.de
}

\begin{abstract}
The transition from a (predominantly) mobile way of life relying on hunting, fishing and gathering to a (predominantly) sedentary life-style based on farming and animal husbandry is considered in the western Pontic archaeological tradition almost exclusively from a southern, AegeanAnatolian perspective. Contacts between the steppe and forest steppe of the north-eastern Balkans and the north-western Pontic were seen as linear and unidirectional; 'cultures' were defined almost exclusively on the basis of pottery styles. Not only such traditional viewpoints, but also the political conditions of the $20^{\text {th }}$ century further biased prehistoric research. However, the outer Carpathian region should not be treated as a periphery of the inner Carpathian Cris culture, but as a region of multidirectional exchange networks. Moreover, certain traditions are obviously rooted in the Mesolithic of that area.
\end{abstract}

IZVLEČEK - Prehod od (pretežno) mobilnega načina življenja, ki je temeljil na lovu, ribolovu in nabiralništvu, na (pretežno) sedentaren način življenja, ki je temeljil na poljedelstvu in živinoreji, se obravnava $v$ arheoloških tradicijah na območju zahodnega Črnega morja predvsem iz južne, torej egejsko-anatolske perspektive. Kontakti med območjema stepe in gozdne stepe na severovzhodnem Balkanu in severozahodnem Črnem morju naj bi potekali linearno in enosmerno; 'kulture' so definirane skoraj izključno na podlagi značilnosti okrasa na lončenini. Poleg tradicionalnih pogledov $v$ stroki so tovrstno pristranskost do prazgodovinskega raziskovanja podkrepile tudi politične razmere $v$ 20. stoletju. Ne glede na to, območje zunanjih Karpatov ne bi smeli obravnavati ločeno od notranje karpatske kulture Criş, saj gre za regijo, kjer so potekale mreže izmenjav v različnih smereh. Poleg tega imajo nekatere tradicije očiten izvor v obdobju mezolitika na tem območju.

KEY WORDS - Eastern Lower Danube area; Prut valley; steppe; forest steppe; Cris culture; 'StarčevoCris IV phenomenon'; exchange networks

\section{History of research}

Traditionally, Neolithic cultures of the forest and coastal steppes of the northern and north-western Pontic regions are known by the names of rivers (Dnepr, Bug, Dniestr), outlining concurrently the geographical area of the respective archaeological culture. This naming was also used for the westernmost exclave of the steppe belt, the Alföld, along the Tisza and Lower Körös rivers. In contrast, in the western Pontic area, and the Balkans in general, those sites that were excavated early in the $20^{\text {th }}$ century gave names to cultures covering geographically diverse entities, extending on both sides not only of broad rivers, but also of steep mountains (e.g., Ka- ranovo or Starčevo cultures). This distinct approach might be explained by the fact that in the forest and coastal steppes no metre-high tell-sites with a vertical stratigraphy and only sites with a horizontal stratigraphy developed during the Neolithic, whereas in Southeast Europe it is precisely such sites that have served as chronological backbones for the whole region and beyond, and all subsequently excavated materials, even from distant areas, were related to such sites.

Additionally, modern history shaped the different terminological systems: the vastness of the north- 
ern Pontic area was not divided into several countries during the $20^{\text {th }}$ century, but was covered by the Soviet Union (USSR). In contrast, the Balkans and the Carpathian Basin were divided by many national borders that additionally shifted during the world wars and had to be renegotiated throughout the $20^{\text {th }}$ century. For example, Romania was submitted to many transformations that are also reflected in archaeological approaches. Therefore, some post-war interpretations need re-appraisal, especially when they touch upon the problematic political relationship between Romania and two of its neighbours during the $20^{\text {th }}$ century. On the one hand, the Kingdom of Romania (1881-1947) and with it Greater Romania (1918-1940) as well as the Socialist Republic of Romania (1947-1989) were in strong competition with its neighbour to the west, the Kingdom of Hungary under the regime of Admiral Horthy (19201944; Fig. 1), followed by the Hungarian People's Republic until 1989. On the other hand, the tense relationship with the dominant Soviet Union (19221991) and, as part of it, the Moldavian SSR (19441991) also did not favour cooperative scientific projects (Fig. 2).

\section{4-1989 in West Romania}

Historical events influenced archaeological interpretations during the $20^{\text {th }}$ century essentially. For example, until 1918 Transylvania was part of the AustrianHungarian Empire, and afterwards part of Romania; between 1940 and 1944 its northern part was under Hungarian rule, and since 1945 it has again been under Romanian administration (Figs. 1, 2). A child of that period, János Banner (1888-1971), received his $\mathrm{PhD}$ in 1911 from the University of Kolozsvár (nowadays Cluj). During connection of northern Transylvania with Hungary, he published his basic book on the TiszaMaros-Körös area (Banner 1942) and led excavations in Hódmezóvásárhely until 1944 . In the same year, there appeared what is still a fundamental book on the Körös culture by Ida Bognár-Kutzian (19192001) (Bognár-Kutzian 1944). Thus, the Early Neolithic (henceforth, EN) of eastern Hungary was defined when Transylvania was under Hungarian rule.

The EN Starčevo culture was named after a site near Pančevo (southeast of Belgrade) excavated in the early and 1944. 1930s (Fewkes et al. 1933). Vladimir Milojčić (19181978) included some of the materials in the $\mathrm{PhD}$ that he submitted in Vienna (Milojčic 1944). Deriving from this study, he published in his influential book on chronology in 1949, in which he established four major phases of Starčevo culture. According to the evolutionist understanding of archaeological cultures of his time, the culture started with a monochrome phase I, evolved through the simple white and later sophisticated polychrome painted phases II-III and ended with phase IV, a phase in decline (the latter being attestable only in northern Serbia (Milojčić 1949.71)). Draga Arandjelović-Garašanin in 1954 and Stojan Dimitrijević in 1974 adopted this system with some changes.

Yet, it was not until 1979 that the EN chronology for western Romania was developed in detail by Gheorghe Lazarovici (*1941). He extended the territory of Starčevo culture from Serbia into western Romania and expanded the periodisation by adding new sub-phases. Although in his view the Körös culture cannot be seen as a group in its own right (Lazarovici 1979.60), he adopted the same name (Criss is the Romanian name for the river Körös - compare Figures 1 and 2) for the EN culture in western Romania. Whereas the first three phases of the StarčevoCris culture were located in the Banat, Transylvania and Oltenia, in phase IV Starčevo-Criş also expanded to Moldova (Lazarovici 1979.53-55). Interestingly, he chose to label with 'Starčevo-Criş IV' (written by him in quotation marks in order to differentiate it from the chronological phase IV) a 'phenomenon' (Lazarovici 1979.55-56) that is not part of the

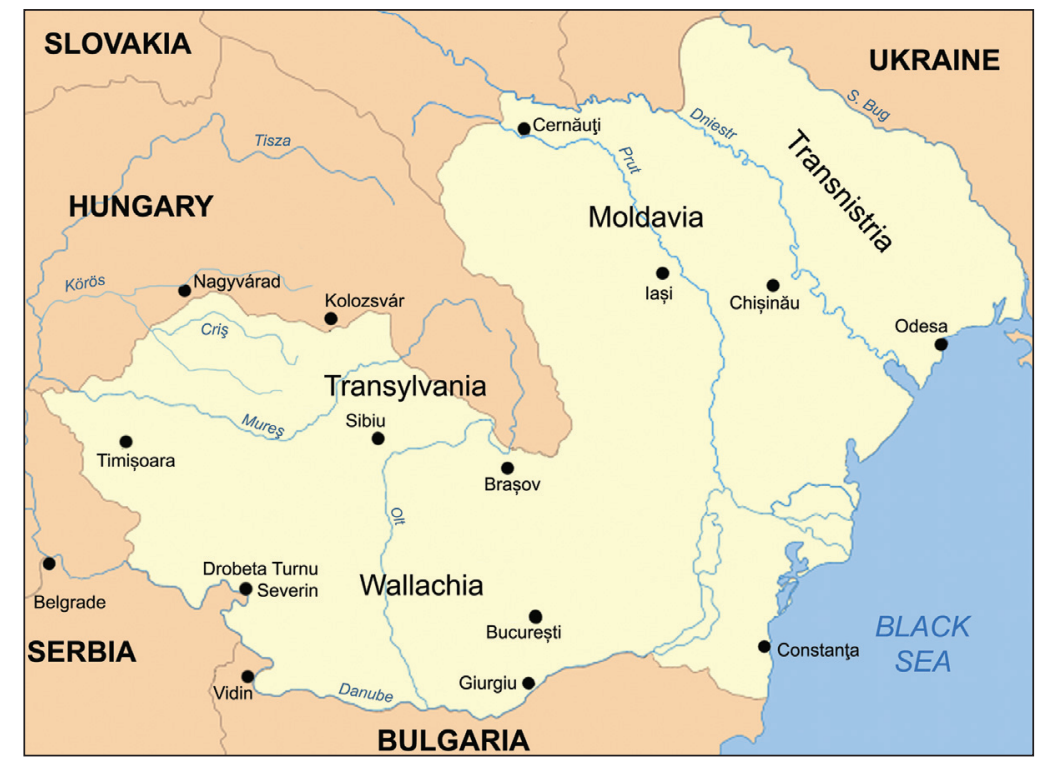

Fig. 1. Territories under Romanian administration between 1941 
Starčevo-Cris culture, but for which no other name would be necessary, although the pottery of the outer Carpathian area, decorated with incisions in zigzags, ripples and channelling, is strikingly different (see below).

In addition to the impediment imposed by national borders, another shortcoming throughout the $20^{\text {th }}$ century was the perpetuation of methodologically outdated approaches. Namely, the uncritical application of Milojčićs' sophisticated, but, without any adjustments (e.g., absolute data) highly problematic system based exclusively on relative chronology led to partial interpretations. Milojčić was very clear about the requirements the method of comparative stratigraphy based on typological comparability involved: not only pottery shapes, but also figurines, ornaments, burial customs, tools, construction techniques, and settlement patterns must be analysed before establishing a temporal relationship between two sites (Milojčić 1949.4-5). These requirements were not always met, either by himself or the generation following him. Instead of describing Starčevo culture based on a detailed analysis of all the elements mentioned above that are essential for the definition of a 'culture', Milojčić used only one of these elements: pottery styles. Moreover, he relied on personal communications from Miodrag Grbič and not on a verified/verifiable analysis (Milojčić 1949.122, footnote 4). Thus, his demand to overcome 'scientific intuition' (Milojčić 1949.1) as a basis for chronological analysis was hardly being achieved, at least not in the case of Starčevo culture. In many subsequent studies, this key method of pre-radiocar-

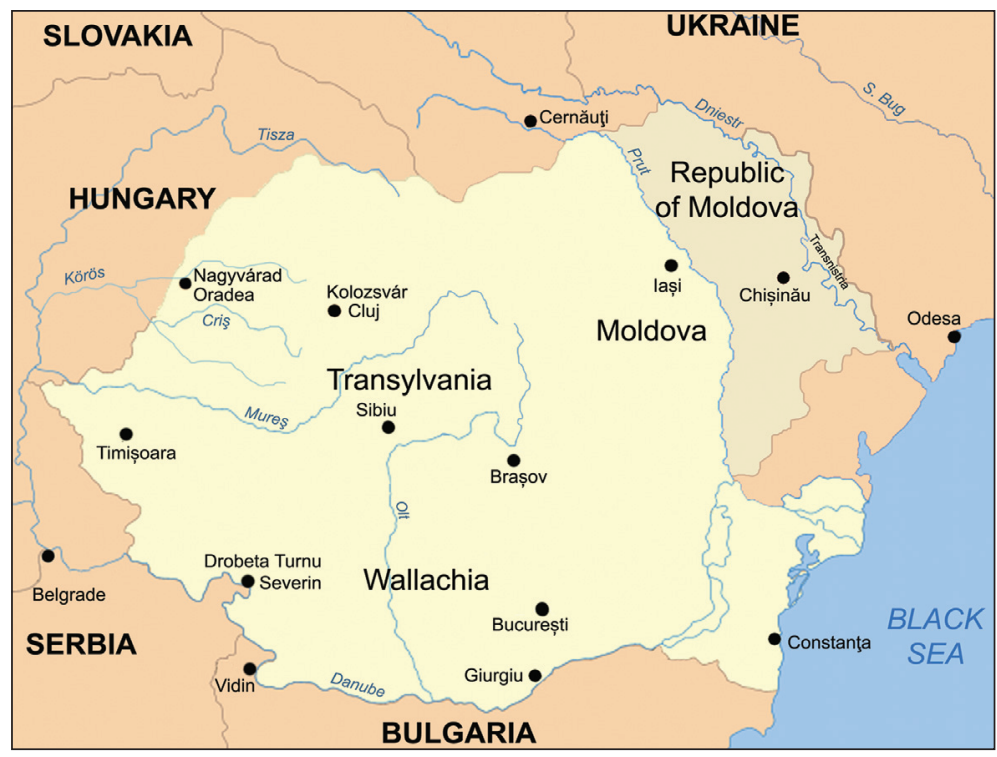

Fig. 2. Romania (after 1947) and the Republic of Moldova (after 1991). bon dating was narrowed down to a comparison of specific pottery traits, stressing single, exceptional elements (the occurrence or absence of paint) rather than working out and elaborating the basic rules. Even Milojčićs strong rejection for ${ }^{14} \mathrm{C}$ dates seems to have persisted in some recent publications.

As a result, the definition of Starčevo culture, and with it of Criş culture, is not grounded on precise stratigraphic observations; on the contrary, the chronological system is based on subjective interpretations and assumptions. Even less helpful was the transplantation of concepts and results from the Aegean to the Balkans, such as the issue of the 'Monochrome Horizon'. Furthermore, the evolutionist approach, characteristic of that time, led to the interpretation of Starčevo IV as a phase in decline, thereby neglecting its importance. Whereas doubts concerning the 'Monochrome Horizon' have lately been advanced (Stojanovski 2014; Krauß et al. 2014; Reingruber in print a), the poorly defined phase IV (contemporaneous with Vinča A) has never been a topic for in-depth analysis.

\section{4-1991 in East Romania}

It was not until 1983 that materials of the EN in the eastern part of Romania, in the counties of Moldova and Bucovina, were analytically studied and considered to pertain to the Criş culture (Ursulescu 1984). Previous interpretations were ignored. Yet, it was Fritz Schachermeyr (1895-1987) who proposed already in 1955 the term 'Glăvăneşti culture' for a specific type of pottery that was first described by Ion Nestor (1905-1974) for the site of Glăvăneştii Vechi near Iaşi (Nestor 1951). In this respect, Schachermeyr was supported by Milojčić (whom he thanked in footnote 67). Milojčić, who can be considered as one of the best connoisseurs of Starčevo and Körös pottery of his time, had not identified common elements between Starčevo pottery and the finds from Glăvăneştii Vechi, and he had not advised Schachermeyr to draw comparisons of this sort. Nevertheless, through two articles published by its representatives in the same year of 1958 the Romanian Academy imposed the view that the whole territory of modern Romania had been uniformly covered by the same Neolithic culture. In a harsh critique, Vladimir Dumitrescu (1902-1991) unequivocal- 
ly rejected the definition of a separate cultural entity, since the outer Carpathian areas were also occupied by Criş culture (Dumitrescu 1958). Mircea Petrescu-Dîmboviţa (1915-2013) also promulgated this view (Petrescu-Dîmbovita 1958). Moreover, Silvia Marinescu-Bîlcu (*1935) insisted that Criş culture had spread not only in Romania, but also in the Soviet Socialist Republic of Moldova (Marinescu-Bîlcu 1981).

This latter claim was remarkable, since the generally accepted view in Soviet times was that the BugDniestr culture had evolved in Moldova (Markevich 1974). But with perestroika and the fall of the Iron Curtain in 1991, almost all sites were redefined as Criss sites instead of Bug-Dniestr (Dergachev et al. 1991; Larina 1994.Fig. 2), except for those sites situated in the Dniestr-valley itself (e.g., Soroca). A more cautious interpretation was given by Klaus $P$. Wechler (2001) who proposed an eastern and western variant of the Bug-Dniestr culture, with strong Criş-influences in the west. Nevertheless, he also accepted the Criş designation, as it is generally still accepted in the archaeological community.

The problems related to research during the $20^{\text {th }}$ century, both during the 'hot' and the 'cold' wars, are manifold. The shifting of national borders and their new negotiations during the 20th century did not favour international research within geographical well-defined entities shared by neighbouring countries. During dictatorships - both rightist and leftist - politically biased research within the confinements of modern states' borders was stimulated, favouring theories and concepts with an inherent and strong national component. History and prehistory were used to legitimise territories repeatedly lost and regained before and after WW II. Certainly, not only in the Balkans, but also throughout Europe, archaeology and nationalism during the last century were "inextricably intertwined" (Díaz-Andreu, Champion 1996.21). Actually, also discourses of our times, as Yannis Hamilakis (1996.977) rightly points out, need careful examination, since subjectivity is inherent in archaeological interpretation.

Apart from the unfavourable historical background, an outdated methodology excluding natural scientific approaches has also led to biased or partial results. The strong focus during post-war research on pottery and stratigraphy, the opening of very narrow but metre-long trenches resulted in mainly limited analysis, further submitted to subjective interpretations. Exceptional painted sherds, always few in the pottery inventories, were used to define whole cultures instead of applying statistical, quantitative ana-

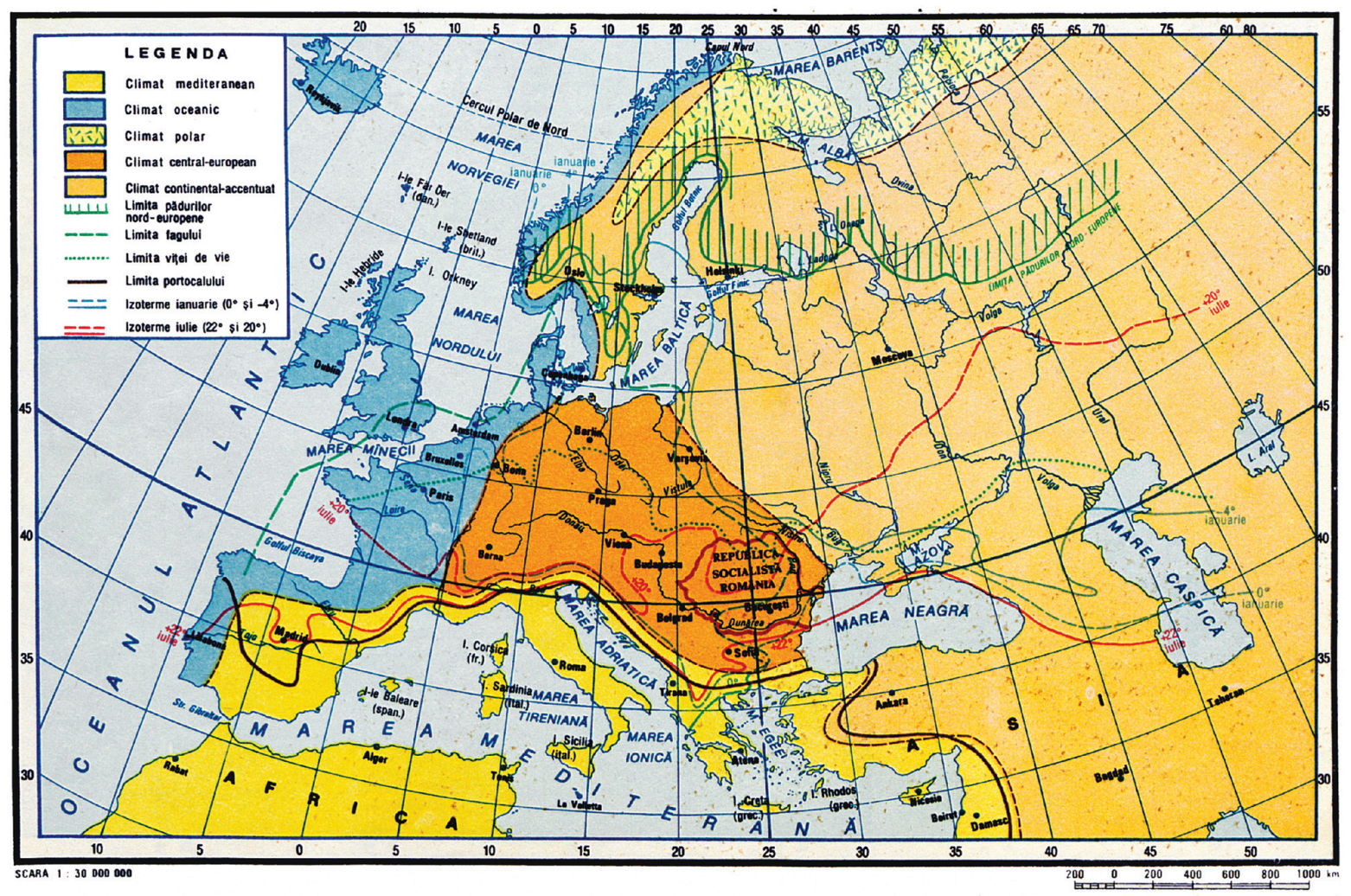

Fig. 3. Map from 1985 showing "Romania's integration in the climate and natural vegetation of Europe" (Atlas 1985.9). The red line corresponds approximately to the limits of the steppe in Fig. 4. 
lysis. In this way, the qualitative method used in the early days of pottery analysis was perpetuated rather than critically re-evaluated. Natural sciences were only casually applied, so radiocarbon dates are even now few and ambiguous.

Nevertheless, with the application of ${ }^{14} \mathrm{C}$ dates, not only must relative chronological sequences be verified, but also the concept of culture as defined mainly by pottery styles be questioned. In a cross-regional comparative approach, priority should be given not to single decorated sherds and poorly defined assemblages, but to the general climatic, ecological, and geographical setting in which people were living and striving, exploiting the given resources and adapting to the environment and its conditions.

\section{Climatic and ecological zones of the inner and outer Carpathians}

During the communist regime in Romania, uniformity was imposed both on society and the economy. Even climate and vegetation were regarded as uniform throughout the territory of the modern state (Fig. 3), so it is not surprising that their advantages and/or disadvantages were not treated in archaeological studies.

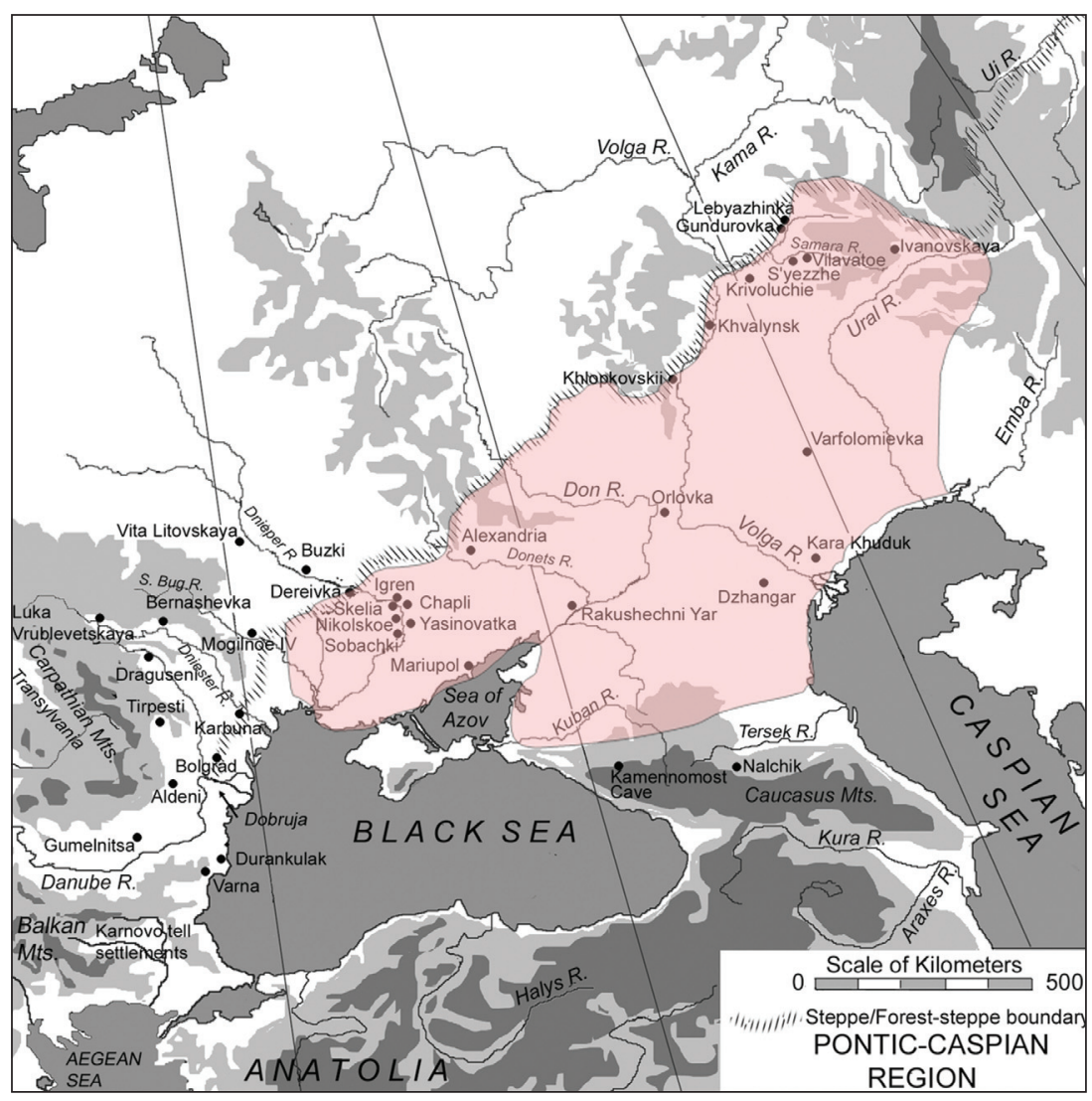

Fig. 4. Extension of the steppe (according to Anthony, Brown 2011.Fig. 4).
Yet, both the climatic conditions and the vegetation cover are diverse, the Carpathian Mountains being a major dividing factor in this respect: they separate the temperate inner Carpathian climate from the more arid conditions of the steppe and forest steppe. Recently reconstructed temperatures for Lake Brazi in the Southern Carpathians accorded with inner Carpathian records (Tóth et al. 2015.578). For the outer Carpathian area, such palaeoclimate reconstructions are still only few (Mayewski et al. 2004; Weninger, Harper 2015). In its western extension, this region is distinguished by the bow described by the Prut and Danube rivers. It is a border region, peripheral to both the arid Pontic steppe farther northeast and to the temperate Balkan zone to the south-west. In Neolithic studies, its connectivity has often been underestimated. Additionally to modern political frontiers, climatic boundaries have also been located between Ukraine and Romania. Generally, only few archaeological maps deal with transfrontier climatic zones, although the Encyclopedia of Earth (Hogan 2013) considers that the steppe also covers southeastern Romania (compare Weninger, Harper 2015.Fig. 3). Even in recent archaeological publications (Anthony, Brown 2011.139, Fig. 4; Gaskevych 2011.Fig. 2) does the Pontic-Caspian steppe stop in the west near the Danube Delta (Fig.

4). The assumed antagonism between the steppic nomads and the sedentary farmers of the Lower Danube area appears thus more aggravated than prehistoric circumstances would allow for.

During the last 100 years, major activities related to deforestation, drainage, river regulation, extensive land use, and overgrazing have changed dramatically both the landscape and vegetation cover. In a region where only few scientific investigations have targeted the reconstruction of the landscape based on drillings and pollen analysis, old maps are especially valuable. Such a map was created by Ellen M. Sanders in 1923, showing the typical mosaic of steppe - wetland - floodplain forest (Fig. 5). Sanders very meticulously describes the 
steppe areas with "no trees" and with "some trees" (i.e. forest steppe, a transitional zone of mixed grasslands and temperate broadleaf and mixed forests). It appears that large areas of the outer Carpathian arch belong climatically to the Pontic steppe region, especially those areas close to the Prut and the eastern Lower Danube. Another area of both primary and secondary steppe stretches along the Tisza River (compare also Tölgyesi et al. 2015), in an area inhabited by the EN Körös culture in the Alföld (Bánffy 2013.Fig. 3).

On the geographical map of the Lower Danube, the dominant feature is the presence or absence of surrounding mountains (Fig. 6). The western area is enclosed on three sides by mountains and forests (up to the River Vedea), and, in contrast, the eastern part is open towards three sides. This favours different directions of prevailing winds and different quantities of precipitation. Whereas in Oltenia (like in the Banat) the Austuru brings warm and dry air from the west at an average of $20-30 \mathrm{~km} / \mathrm{h}$, in Muntenia, as well as in Moldova and Dobrogea, the Cri$v a ̆ t u l$, a strong wind reaching up to $120 \mathrm{~km} / \mathrm{h}$, sweeps from the east with cold air and blizzards in winter and hot and dry air in summer. Hence, in the western part, precipitation is between $500-700 \mathrm{~mm} / \mathrm{a}$, whereas in the eastern part, precipitation is less than $400 \mathrm{~mm} / \mathrm{a}$ (Atlas 1985). Certainly, this has a strong influence on the vegetation cover: much of the outer Carpathian bow is covered primarily by steppe grasses and open forests of the silvosteppe, interspersed with wet meadows in the river valleys. Therefore, both climate and vegetation are comparable to that of the north-western Pontic steppe region.

That we do not deal in Muntenia with secondary steppe areas is proven by investigations carried out by an interdisciplinary team working in Pietrele, jud. Giurgiu. There, for the $5^{\text {th }}$ millennium BC, the bones of steppe-preferring species such as horses and aurochs, as well as a high percentage of grasses in the pollen record were attested (Benecke et al. 2013; A. Röpke in Hansen et al. 2012).

The Lower Danube Region is thus far from being climatically uniform, but divided into different zones. The zone extending over both the eastern Lower Danube area and the Prut-Siret area is described as arid. The transitional zone between sub-Mediterranean and arid areas runs along the Vedea and Teleorman rivers north of the Danube and the Yantra south of the Danube (Atlas 1985.28, 42-43). This line (Fig. 6) can be regarded as an approximate separation between a western area (part of the temperate zone of Southeast Europe) and an eastern one (part of the much more arid zone of the Pontic region).

In the modern era, these zones and their 'ecological biogeography' (Huggett 2004) are of little relevance. But populations responding to their physical and living surroundings, to both the abiotic (e.g., temperature, soils, water, air currents) and the biotic environment (different species, parasites, diseases, predators) were dependent on these factors. Differences in ecozones were certainly of major importance in pre-Neolithic times, when Mesolithic communities relied on their biomasses. With the emergence of a producing economy and the import of domesticated species, such dependencies were of less importance. If the view proposed here is accepted, whereby local Mesolithic communities participated actively in the Neolithisation process, then these ecozones should be considered as relevant also for the EN period.

\section{Limits in the definition of archaeological cul- tures: the case of the 'Starčevo-Criş IV pheno- menon'}

In the traditional view, the definition of an archaeological culture is based mainly on material culture (Wotzka 2014.139-144). Following Philippe Descola (2014.39), cultures can be further outlined according to their geographical boundaries. Not only are the remains of Criş culture east of the Carpathians insufficiently described, but also the geographical setting in- and outside the Carpathian Basin, two climatically and geographically quite distinct zones, has hardly ever been discussed. The easternmost stretches of the Pannonian Plain ('Câmpia de Vest', in western Romania) are bounded by the three Criş rivers (Fig. 6), but the sites labelled as Criss are in fact not located in the Crişana, the Criş Basin, but farther east, in the Somes catchment and farther south, in the catchments of the Mures (Transylvania) and Timiş (Banat) rivers. This, for non-specialists, slightly confusing situation is further impaired by the transfer of the culture's name Cris to the east (the county of Moldova and the Republic of Molodova). As a result, the earliest Neolithic evidence in the outer Carpathian bow, extending as far east as the Dniestr, is named after a river's course from west of the mountains either as Criş or as 'Starčevo-Criş IV' (compare Lazarovici 1979, above). Thus it must be possible to ask on what grounds the definition of this culture relies (apart from pottery styles), and how well-founded is its interpretation as a comprehensive cultural phenomenon (apart from the effort to sub- 
sume Neolithic cultures occupying the territory of present-day Romania under the same label).

No clear boundaries and no geographically or climatically well-defined area can thus be connected to Criş culture, as it is supposed to have spanned both the inner and outer Carpathian regions. The latter, the Prut-Danube region, is climatically a steppe/forest steppe area. Rather than attaching this climatically, hydrologically, and culturally distinct region to the inner Carpathian basin, it should be envisaged as an important and not interchangeable living environment in its own right. The transition from the Mesolithic to the Neolithic in the Prut-Danube area should not be viewed through results obtained elsewhere, nor should assumptions be built on them, but be described according to the conditions given in the area east of the Carpathians.

Apart from the lack of well-defined geographical boundaries, the temporal limits of the culture are also vague. When one compares ${ }^{14} \mathrm{C}$ dates from different sites of Criş culture, the problematic division into phases and, moreover, the deficiencies deriving from poorly applied stratigraphic comparisons become obvious, even for the heartland of the culture (Reingruber, Thissen 2016; Thissen, Reingruber in print). The first phase, Pre-Criș, is presumed to have antedated the $6000 \mathrm{BC}$ margin by several hundred years (Ciută 2005.124), similarly to Proto-Starčevo (Srejovic 1988) and Pre-Karanovo (Todorova 2003). These early stages were connected to an allegedly 'Monochrome Horizon'. As has been shown else-

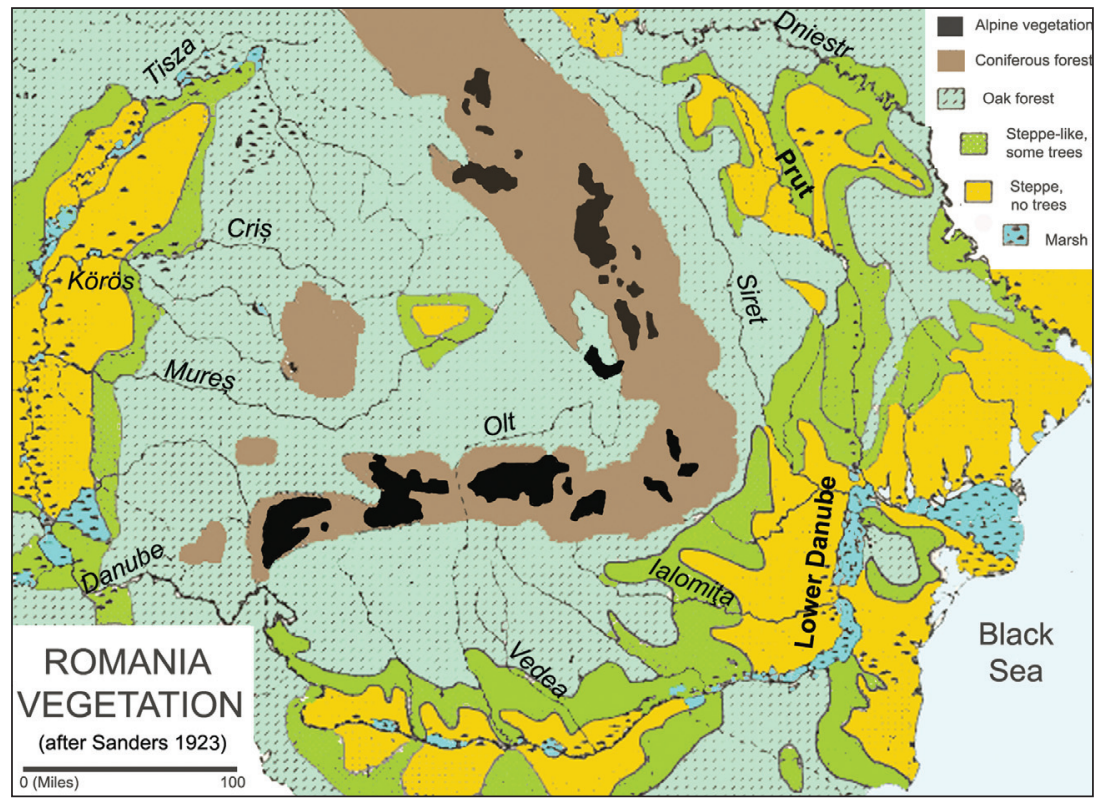

Fig. 5. Climatic map of Romania and neighbouring areas (after Sanders 1923.387). where (Reingruber in print a), this horizon cannot be verified stratigraphically in the whole of the Balkans. Its ${ }^{14} \mathrm{C}$ dates vary between 6000 and 5500 BC (Reingruber, Thissen 2016), and cover the whole duration of Starčevo-Cris culture; therefore, monochrome pottery is not limited to a distinct phase, but concomitant with all other phases. Apart from this, the concept of the 'Monochrome Horizon' derives from the Thessalian EN (Reingruber 2008. 211-213) and is not directly applicable to pottery from the Middle and Lower Danube area, especially not to the Ludogorie Plateau in north-eastern Bulgaria. There, the pottery of the Koprivets culture (5900-5700 BC) has been linked to the (not only unpainted but also undecorated) Aegean 'Monochrome Horizon' (c. $6400 \mathrm{BC}$ ), although the vessels from Koprivets are decorated with impressions, incisions and plastic knobs (Fig. 7). Interestingly, incisions and impressions and the absence of paint are characteristic and defining elements of Bug-Dniestr pottery of the early $6^{\text {th }}$ millennium BC (Wechler 2001). In the intermediate region of the Prut and Siret rivers again this kind of ornament prevailed in the pottery of the mid-6th millennium BC (Fig. 8). Therefore, rather than claiming direct contacts with distant Aegean regions solely due to the absence of paint, the (also unpainted) pottery inventories of the directly neighbouring Pontic region should be envisaged for comparisons first.

Especially poorly defined is the final stage of the EN. Owing to an evolutionist perception of pottery production and of cultural development in general, the last phase of Criş culture was thought to be one of decline and decay: paint was no longer applied, pots were of rougher appearance (Ursulescu 1984.31-34, 37). This interpretation justified the designation of sites from the outer Carpathian bow as Cris, making a more thorough and independent analysis of the material culture seemingly dispensable, even though the (indeed only few) absolute dates pointed not to a co-existence but to a temporal succession between Starčevo-Criş and the 'Starčevo-Criş IV phenomenon'. Starčevo-Criş culture ends in the west, in Serbia, according to ${ }^{14} \mathrm{C}$ dates around 
5500 BC (Thissen, Reingruber in print). In the outer Carpathian area of Oltenia (southwest Romania) the 'Starčevo-Criş IV phenomenon' has been dated at Cârcea Viaduct and Valea Răii-Copăcelu to 5400-5300 BC (Mantu 1999-2000.98). In Moldova, at the Trestiana site (Popuşoi 1983.36), the 'Starčevo-Criş IV phenomenon' is assumed to have started around 5500 BC, ending with 'Music Note Pottery', a late variant of Linearband culture (LBK) at c. $5300 \mathrm{BC}$ (Reingruber in print a). At the moment, we do not possess enough data to characterise these two important centuries, between 5500 and $5300 \mathrm{BC}$, harbinger of major transformations in both the Lower and Middle Danube areas with the transitions to the Karanovo III and Vinča cultures. Yet the contribution from the Prut-Danube region to the formation of cultures further upstream from the Danube, like Dudeşti at $5500 \mathrm{BC}$ (Thissen in print) and Vinča at 5300 BC (Schier 1996), should not be underestimated.

\section{The Prut-Danube network of the north-western Pontic steppe: burial rites and stone tools}

Hence, a well-founded analytical description of a presumed cultural unity spreading both east and west of the Carpathian Mountains has not yet been provided. Pottery styles would rather point to largely independent, and radiocarbon dates to subsequent, phenomena regarding the Starčevo-Criş cultures in the west and 'Starčevo-Criş IV' in the east. Certainly, pottery styles do display regional variations, but throughout the whole area of the Prut-Danube river system they are (almost exclusively) unpainted and bear decorations that are incised and/or impressed. This is a characteristic that can also be claimed for the westernmost exclave of the steppe belt, the territory of Körös culture, where pottery surfaces were roughened by joining additional clay (barbotine), paint being applied only exceptionally. Recently, Mihael Budja has pointed out, in a wider European context, two major pottery traditions: a northern one, never painted, embedded within a hunter-gatherer context and a southern one, with coloured decoration, connected to early farming communities of Near-Eastern origin (Budja 2015.546, Fig. 28.5).
Pottery styles as described above (Figs. 7-8) are only one feature pointing to a network of contacts and exchange. Shared traditions are also traceable in other cultural features. The dominant funerary burial tradition in western Ukraine entailed burial in the supine position (Gaskevych 2015), unlike Aegean rites in which bodies were placed out in a crouched, hocker position (Lichter 2002). Inhumation in an extended supine position was also a common practice during the Mesolithic of the Iron Gates (Boroneant, Bonsall 2012), but in Lepenski Vir it was replaced after $6000 \mathrm{BC}$ by the hocker position (Boric 2015). Along the eastern Lower Danube area and the Black Sea coast (Cernica and Cernavodă, Durankulak and Varna), the supine burial position was used even during the late $6^{\text {th }}$ and $5^{\text {th }}$ millennia (Lichter 2001.151-152). For this reason, Lichter concludes that Mesolithic burial traditions in these regions survived until the Copper Age (Lichter in print). Furthermore, certain animal sacrificial rites in this area are, according to Valentina Voinea (2010), not only of Pontic but even of earlier Mesolithic traditions.

A strong argument for substantiating Pontic traditions and influences in the Balkans are chipped stone tools, especially bullet cores used to produce parallel-

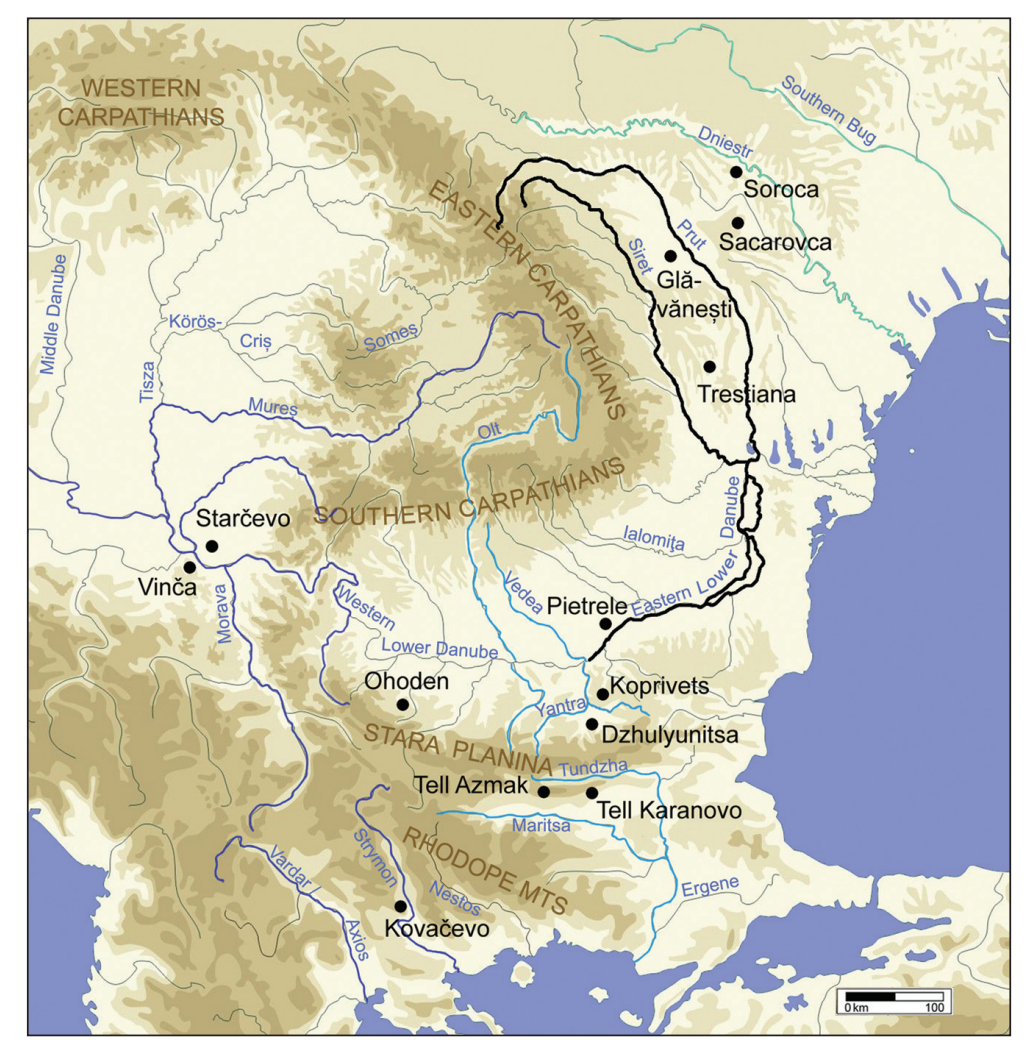

Fig. 6. Topographical map with the mountainous arc described by the Carpathians and its continuation into a southern arc which, with Stara Planina, surrounds the western Lower Danube area. 


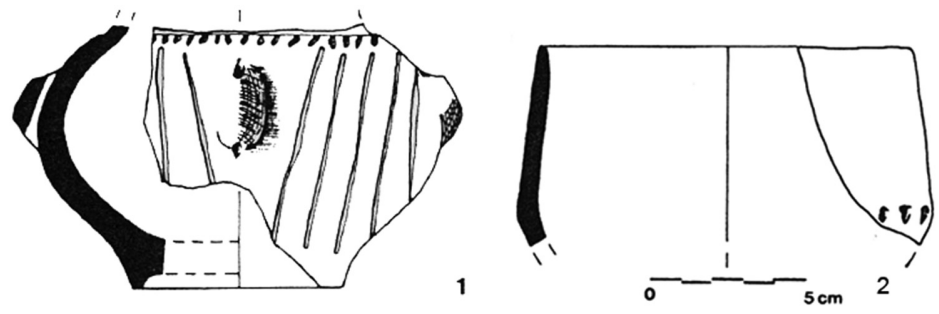

1
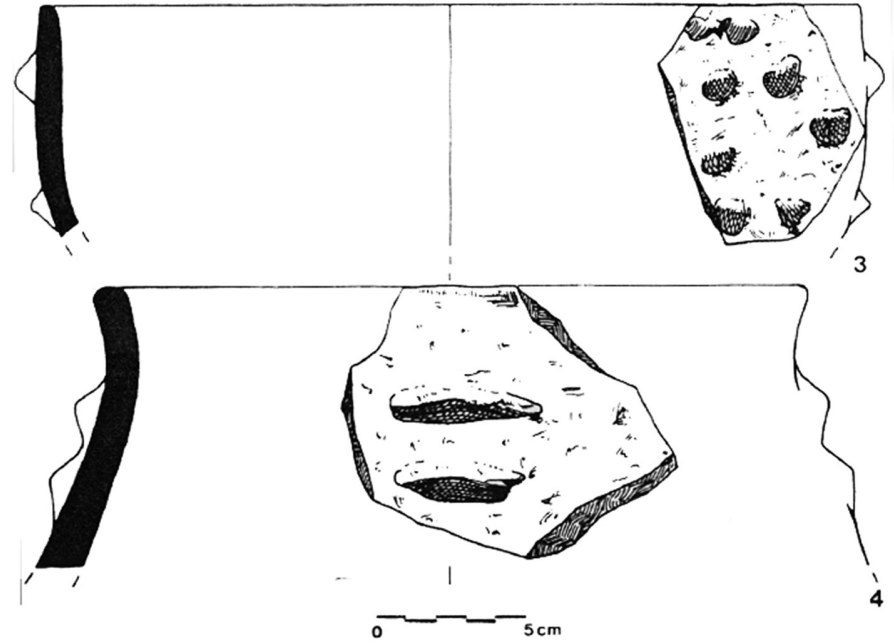

Fig. 7. Pottery from Koprivets (after Stefanova 1996).

in phases Ic-Id (dated to after $5700 \mathrm{BC}$; Reingruber, Thissen 2005) by so-called macroblades.

The macroblade industry prevailed throughout the EN in Thrace. From single-platform cores, big regular blades were removed by punching with a hard hammer; also characteristic is the subsequently applied high and steep retouch (Gatsov et al. in print.Fig. 1). Interestingly, a specific kind of flint, a high-quality yellow flint with white spots, so-called 'Balkan flint' (henceforth $\mathrm{BF})$ is related to this technique (Gurova 2008.Figs. 2-12). The flint most probably derived from the Pleven-Nikopol region in NNW Bulgaria (Gurova 2014.95), where it was extracted until c. $5500 \mathrm{BC}$; afterwards, its use declined in the Karanovo III/IV period.

North of Stara Planina, the use of BF started in the so-called Pre-Karanovo period, or rather the Koprivets culture

sided bladelets. Ivan Gatsov recently pointed out that bullet core technology is of Anatolian origin and probably did not continue north of the Sea of Marmara, since in Bulgaria no such items have (yet) been found (Gatsov et al. in print). One could argue that, generally, very little is known from the Mesolithic in present-day Bulgaria, a period that should especially be targeted in future investigations. As Paolo Biagi and Dmytro Kiosak have shown for areas further north, bullet cores and the fine regular blades obtained from them, are typical of the Mesolithic cultures of south-western Ukraine, especially the Kukrek and Grebenyky cultures, which spread as far west as the Prut (Biagi, Kiosak 2010.23-24). From its most important site, Myrne, close to the northernmost Chilia branch of the Danube Delta, geometric microliths (isosceles and rectangular trapezes) and bullet cores were recently dated to $7500-$ 7300 BC (Biagi, Kiosak 2010.Fig 1, Tab. 3).

According to some authors, there are no differences between the tools of the Kukrek cultures and the north-western Pontic 'Tardenoisian' of Romania (Biagi, Kiosak 2010.25). Also, for northern Bulgaria a century-long use of microliths has been pointed out: in Ohoden, trapezes and segments were in use throughout the occupation (Gurova 2014.97), dated to $c .5700-5600 \mathrm{BC}$ (Thissen, Reingruber in print). Further south, in Kovačevo, they were replaced only
(Vajsov 2002), and is attested in the lowest levels of Dzhulyunitsa around $6050 \mathrm{cal} \mathrm{BC}(\mathrm{Krau} \beta$ et al. 2014). South of Stara Planina, in the lowest levels of Tell Azmak and Tell Karanovo, its use can be dated to only after 5900/5800 BC. Farther south, in southwest Bulgaria, it does not occur in the earliest Neolithic occupation phase at Kovačevo but only in later ones.

Maria Gurova (2014.96) draws our attention to the fact that in north-eastern and northern Bulgaria, no macroblades ('formal tools', in her words) were in use in early contexts (e.g., Ohoden and Dzhulyunitsa). Consequently, Gurova and Clive Bonsall refer to different traditions north and south of Stara Planina (Gurova, Bonsall 2014.103). This very limited evidence may, nevertheless, indicate that the Neolithic use of BF began earlier in northern Bulgaria and, one would add, since the sources are in the north, it might be indicative of an exchange network already in use there before it expanded across the Balkan Mountains towards the south.

\section{Discussion: cultures and networks}

The elements required to define archaeological cultures were enumerated by, for example, Milojčić (supra) in the mid-20th century; their territorial boundaries often coincided with the national bor- 
ders of the time. Changes were mainly explained by massive unidirectional migrations, by 'penetrations' from area A into area B (Ursulescu 1984). Yet, for an explanation of the complex transformation processes that led, for example, to the Neolithisation of Southeast Europe around $6000 \mathrm{BC}$ or to the transition from the MN to the $\mathrm{LN}$ around $5500 / 5300 \mathrm{BC}$, such approaches, if they exclude the natural sciences, are insufficient. It is essential to understand transcultural and diachronic networks based on reciprocity and exchange, developing in a given ecological setting and using natural communication and transportation routes. In this perspective, pottery is only one among several elements to be studied: at least as important are studies of raw material sources and their distribution, of animal bones, of human remains. No palaeogenetic or isotopic determinations have been carried out on individuals from the Prut-Danube area, but the studies of human bone material from

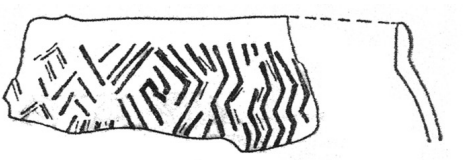

1
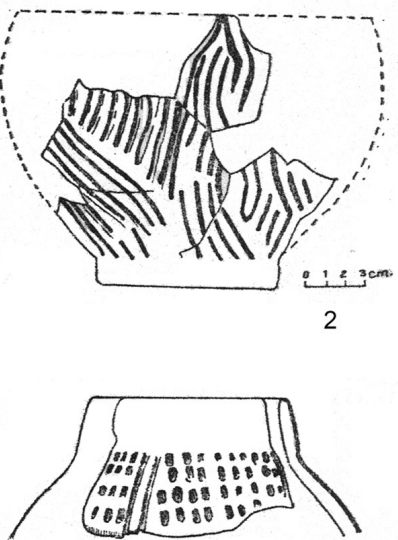

3
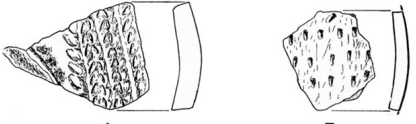
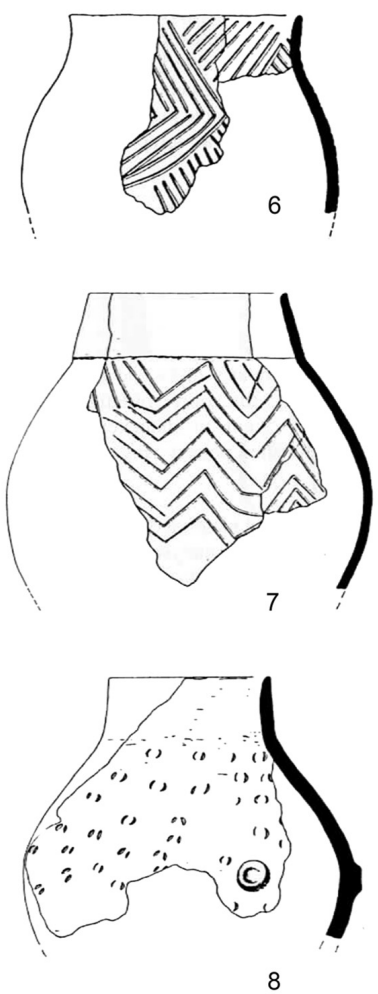

Fig. 8. 1-5 pottery from Trestiana (after Ursulescu, Dergachev 1991.Fig. 3; Popuşoi 1983.Fig. 4.12-13); 6-8 pottery from Sacarovca (after Dergachev et al. 1991.Fig. 4). two Körös sites yielded astonishing re-

sults: the genome of a male from the more northerly farming site of Tiszaszólós-Domaháza (c. 5700 BC) displays a hunter-gatherer background, whereas the genome of a female up to 100 years younger from the more southerly site of Berettyóuifalu-Morotva-liget clusters with later Neolithic individuals (Gamba et al. 2014.3, Tab. 1). Although two samples are a very thin basis for drawing any conclusions, it appears that in the steppe area of the Körös region, direct contacts between Mesolithic and Neolithic groups occurred. On a much broader basis, a system of patrilocal residential rules among early farmers was indeed proposed by Anna Szécsényi-Nagy et alii (2015). This corresponds well with results obtained by Dušan Borić and Douglas T. Price (2013) from the Danube Gorges based on isotopic studies in which mainly women were of extra-local origin.

In all three interconnected areas of the Prut-Danube river system - the area covered by 1) the Koprivets culture in north-eastern Bulgaria (as defined by Ivan Vajsov), 2) the area of the 'Starčevo IV phenomenon' in Muntenia and Moldova (as defined by Gheorghe Lazarovici) inclusive of Glăvănești culture (as it was named by Fritz Schachermeyr, but not accepted in the Romanian literature), and 3) the area of the for- mer Bug-Dniestr culture in the Republic of Moldova (redefined as Criş) - we meet similar characteristics, both climatically, hydrologically, and culturally.

Here, it is plausible that an exchange network existed along the outer Carpathian area. According to the conventions of the terminology used for Neolithic cultures in the steppe, this network should be named after the major rivers of the region, the Prut and Danube. The network was in use already during the Mesolithic (according to evidence from stone tools) and was afterwards enlarged in Neolithic times (according to evidence from pottery). The radiocarbon dates for the sites participating in this network are few and often ambiguous: dates even older than $6000 \mathrm{BC}$ derive from the northern sites west of the Dniestr (e.g., Soroca II-Trifăuţi), but they must be treated with caution (Gaskevych 2010). From its central part, the oldest dates are 5900-5700 BC (e.g., Poiana Slatinei - compare Weller, Dumitroaia 2005. Fig. 6), and the dates from the southern reaches (the Koprivets culture) are similar. The network can be followed up until at least 5500/5300 BC (e.g., Soroca $\mathrm{V}$ and Trestiana) (Thissen, Reingruber in print). Subsequently, an expansion along the Danube towards the west is marked by the pottery with Notenkopf (Music Note) decoration, which is found in 
Pietrele and Vădastra (Reingruber in print a.Fig. 1). Therefore, major transcultural networks can be pointed out that developed along the different river systems (highlighted in different colours on Fig. 6):

- operating along the Axios/Vardar-Struma-Morava rivers and Danube-Timiş-southern Tisza-Mureş (Nikolov in print) and along the Maritsa-Tundzha and Yantra-Vit-Vedea-Olt (Reingruber in print $b$ ) is the network that connects the Balkans and the inner Carpathians, comprising roughly the archaeological cultures of Amzabegovo-Vršnik, Karanovo and Starčevo-Criş with, e.g., white painted vessels, hocker burials and with a macroblade technology as well as tell-settlements (in Thrace).

- another network is that of the steppe and forest steppe, comprising the sites both west and east of the river Prut (formerly ascribed to Bug-Dniestr culture or attributed to the 'Starčevo-Criş IV phenomenon') and sites of the eastern Lower Danube catchment. It is characterised by incised and impressed decorations on pots, flat settlements (if tells formed, then only late, after $4800 \mathrm{BC}$ ), supine burial positions and simple blade technology.

The different networks are connected in the eastwest and west-east directions by the Danube, which facilitated communication and exchange between the regions.

Building upon Richard Huggetts ecological biogeography, three zones can be defined for Southeast Europe:

- the First Neolithic of the circum-Aegean zone, starting around 6700/6600 BC (Reingruber 2015), covering the Mediterranean subtropical zone (Huggett 2004.102) between roughly $35^{\circ}$ and $42^{\circ}$ north;

- the First Temperate Neolithic of the Balkans and eastern Central Europe, between 6000 and 5500 BC (Thissen in print) in the Humid mid-latitude zone (Huggett 2004.102) of SE Europe, north and south of the $45^{\text {th }}$ parallel north;

- the First Neolithic of the western and north-western Pontic steppe and forest steppe of the Arid midlatitude zone (Huggett 2004.102), with an early stage between 5900-5500 BC and a later stage between 5500-5300 BC.

As indicated in Fig. 6, these zones were interconnected by the courses of the different rivers that were essential for maintaining transcultural exchange networks. Especially in present-days northeastern Bulgaria, a contact zone between the two latter entities emerges: concerning, the white painted pottery of the Thracian tradition appears also on the northern fringes of Stara Planina, whereas in the Ludogorie basically incisions and impressions of steppe traditions were used; on the other hand, the raw material was from the Nikopol region, highly valued also south of Stara Planina.

\section{Conclusions}

The Neolithic discoveries west of the Dniestr River are in the opinion of both Moldavian (Dergachev et al. 1991) and Ukrainian archaeologists (Nadja Kotova, personal comm. 07.11.2015) indeed different from Bug-Dniestr material culture. According to the above notions, it is also different from the inner Carpathian Criş culture. It is therefore not advisable to speak of Criş culture (in its Starčevo variant) in the outer Carpathian area, in areas of present-day eastern Muntenia and Moldova, since the basic criteria for the definition of a culture are not met, not to speak of the extremely different ecosystem of the inner and the outer Carpathian arch. Yet, for the outer Carpathian area pottery styles, burial traditions, and tool manufacturing attest to a certain degree of exchange, even to perpetuations of traditions from the previous Mesolithic period. Facilitated by the Prut, Danube, and Siret rivers, a network was established in this region that operated simultaneously with those west of the Carpathians or south of the Balkan Mountains (Fig. 6). It certainly deserves more careful and detailed treatment in the future.

The more thoroughly we are able to understand and accept the Prut-Danube area as an interconnected network system of its own, not caught between nationalist and politically motivated approaches, the better are the chances of understanding developments in the broader area between 5900 and 5300 BC. Anatolian-Aegean-centric views do not explain all the transformations appearing after $6000 \mathrm{BC}$ in the northern Balkans, especially not those occurring after $5500 \mathrm{BC}$. Around the middle of the $6^{\text {th }}$ millennium BC, major transformations have been noted, like the shift to largely unpainted pottery styles and the exploitation of new raw material sources in $\mathrm{Ka}$ ranovo III and Vinča A phases. The beginning of the Dudeşti cultures in Muntenia and Vinča-Dudeşti in Oltenia in particular are poorly defined. In terms of radiocarbon dates, the site of Măgura-Buduiasca near 
Alexandria antedates the Vinča tell by $c .200$ years (Thissen, Reingruber in print). These two centuries, 5500-5300 BC, will hardly be understood without acknowledging the contribution and role played by the Prut-Danube area in the formation or expansion of networks in the western Lower Danube area and even farther upstream after 5500 BC. Future inter- disciplinary trans-regional and trans-frontier studies will certainly help clarify some of misunderstandings and problems we are confronted with nowadays. The input and importance of this network in transformation processes following the Danube farther upstream certainly will then be better appreciated.

I am especially grateful to Clemens Lichter and Laurens Thissen for sharing their views on burial customs and Early Neolithic pottery production with me. I further wish to thank Ivan Gatsov, Petranka Nedelcheva, and Vassil Nikolov for allowing me to use unpublished manuscripts. I am much obliged to the two anonymous reviewers who contributed to clarifying the line of argument.

\section{References}

Anthony D. W., Brown D. R. 2011. The Secondary Products Revolution, Horse-Riding, and Mounted Warfare. Journal of World Prehistory 24: 131-160.

Arandjelović-Garašanin D. 1954. Starčevačka kultura. Univerza v Ljubljani. Arheološki seminar. Ljubljana.

Atlas 1985. Atlas Geografic: Republica Socialistă România. Editura didactică şi pedagogică. Bucureşti.

Bánffy E. 2013. The Early Neolithic in the Danube-Tisza interfluve. Archaeolingua Central European Series 7. British Archaeological Reports IS 2584. Archaeopress. Oxford.

Banner J. 1942. Das Tisza-Maros-Körös-Gebiet bis zur Entwicklung der Bronzezeit. Archäologisches Institut der Miklós Horthy-Universität. Szeged.

Benecke N., Hansen S., Nowacki D., Reingruber A., Ritchie K. and Wunderlich J. 2013. Pietrele in the Lower Danube region: integrating archaeological, faunal and environmental investigations. Documenta Praehistorica 40: 175-193.

Biagi P., Kiosak D. 2010. The Mesolithic of the northwestern Pontic region: New AMS dates for the origin and spread of the blade and trapeze industries in southeastern Europe. Eurasia Antiqua 16: 21-41.

Bognár-Kutzian I. 1944. A Körös kultúra. Institut für Münzkunde und Archäologie der Péter Pázmány Universität. Budapest.

Borić D. 2015. Mortuary practices, bodies and persons in the Neolithic and Early-Middle Copper Age of Southeast Europe. In Chr. Fowler, J. Harding and D. Hofmann (eds.), The Oxford Handbook of Neolithic Europe. Oxford University Press. Oxford: 927-957.
Borić D., Price T. D. 2013. Strontium isotopes document greater human mobility at the start of the Balkan Neolithic. Proceedings of the National Academy of Sciences USA 110(9): 3298-3303.

Boroneant A., Bonsall C. 2012. Burial practices in the Iron Gates Mesolithic. In R. Kogălniceanu, R.-G. Curcă, M. Gligor and S. Stratton (eds.), Homines, Funera, Astra. Proceedings of the International Symposium on Funerary Anthropology, Alba Iulia 2011. British Archaeological Reports IS 2410. Archaeopress. Oxford: 45-56.

Budja M. 2015. Pots and Pottery in the Mesolithic-Neolithic Transition in South-East Europe. In Chr. Fowler, J. Harding and D. Hofmann (eds.), The Oxford Handbook of Neolithic Europe. Oxford University Press. Oxford: 535-553.

Ciută M.-M. 2005. Inceputurile neoliticului timpuriu în spatiul intracarpatic transilvănean. Aeternitas. Alba Iulia.

Dergachev V., Sherratt A. and Larina 0. 1991. Recent results of Neolithic research in Moldavia (USSR). Oxford Journal of Archaeology 10(1): 1-16.

Descola Ph. 2014. Die Ökologie der Anderen: Die Anthropologie und die Frage der Natur. Matthes \& Seitz. Berlin.

Díaz-Andreu M., Champion T. (ed) 1996. Nationalism and Archaeology in Europe. University College London Press. London.

Dimitrijević S. 1974. Das Problem der Gliederung der Starčevo-Kultur mit besonderer Rücksicht auf den Beitrag der südpannonischen Fundstellen zur Lösung dieses Prob- 
lems. In Les débuts des civilisations agricole en Voivodine er an Serbie danubiennes. Materijali 10: 93-107.

Dumitrescu V. 1958. Review: Fritz Schachermeyr, Die ältesten Kulturen Griechenlands, Kohlhammer, Stuttgart 1955. Studii şi Cercetări de Istorie Veche şi Arheologie 9(1): 195-204.

Fewkes V., Goldman H. and Ehrich R. 1933. Excavations at Starčevo, Yugoslavia, seasons 1931 and 1932. A preliminary report. Bulletin of the American School of Prehistoric Research 9: 33-54.

Gamba C. and 16 authors. 2014. Genome flux and stasis in a five millennium transect of European prehistory. Nature Communications 5: 1-9.

Gaskevych D. 2010. Severo-pontiyskoe impresso: proiskhozhdenie neoliticheskoy keramiki s grebenchatym ornamentom na yuge Vostochnoy Evropy (North-Pontic Impresso: Origin of the Neolithic Pottery with Comb Decoration in the South of Eastern Europe). Stratum Plus 2010 (2): 213-251. (in Russian)

2011. A new approach to the problem of the Neolithisation of the North-Pontic area: is there a north-eastern kind of Mediterranean Impresso pottery? Documenta Praehistorica 38: 275-290.

2015. Pogrebenyya Bugo- dnestrovskoy neolytycheskoy kul'turi: kriticheskij analiz istochnikov (Burials of the Bug-Dniestr Neolithic culture: a critical analysis of sources). Stratum Plus 2015(2): 181-206. (in Russian)

Gatsov I., Nedelcheva P., Kozłowski J. and Kaczanowska M. in print. Lithic industries and their role in Neolithisation models in Southeast Europe. In A. Reingruber, Z. Tsirtsoni and P. Nedelcheva (eds.), Going West? The Dissemination of Neolithic Innovations between Bosporus and the Carpathians. Proceedings of the EAA Conference, Istanbul 2014. EAA Monograph Series: Themes in Contemporary Archaeology. Taylor \& Francis Group, Abingdon-on-Thames. In print.

Gurova M. 2008. Towards an understanding of Early Neolithic populations: a flint perspective from Bulgaria. $\mathrm{Docu}$ menta Praehistorica 35: 111-129.

2014. Neolithic flint assemblages from Bulgaria. An overview. Samarskij naučnyj vestnik 3(8): 94-107.

Gurova M., Bonsall C. 2014. 'Pre-Neolithic' in Southeast Europe: a Bulgarian perspective. Documenta Praehistorica 41: 95-109.

Hamilakis Y. 1996. Through the looking glass: nationalism, archaeology and the politics of identity. Antiquity 70 : 975-978.
Hansen S. and 13 co-authors. 2012. Pietrele an der Unteren Donau. Bericht über die Ausgrabungen und geomorphologischen Untersuchungen im Sommer 2011. Eurasia Antiqua 18: 1-68.

Hogan C. M. 2013. Pontic steppe. Retrieved from http:// www.eoearth.org/view/article/178216 Published: July 21, 2012, 12:00 am, Updated: April 30, 2013, 4:11 pm. Last accessed 3.3.2016.

Huggett R. J. 2004. Fundamentals of Biogeography. Routledge fundamentals of physical geography series. Psychology Press. London, New York.

Krauß R., Elenski N., Weninger B., Clare L., Çakırlar C. and Zidarov P. 2014. Beginnings of the Neolithic in Southeast Europe: the Early Neolithic sequence and absolute dates from Džuljunica-Smărdeš (Bulgaria). Documenta Praehistorica 41: 51-77.

Larina 0. 1994. Culturi din epoca neolitică. Ştiinţa. Chişinău.

Lazarovici Gh. 1979. Neoliticul Banatului. Bibliotheca Musei Napocensis, IV. Comitetul pentru cultură şi educaţie socialistă al judeţului Cluj. Cluj-Napoca.

Lichter C. 2001. Untersuchungen zu den Bestattungssitten des südosteuropäischen Neolithikums und Chalkolithikums. Heidelberger Akademie der Wissenschaften. Internationale Interakademische Kommission für die Erforschung der Vorgeschichte des Balkans V. Zabern. Mainz.

2002. Burial customs of the Lower Danube and Eastern Balkans in the Neolithic and Chalcolithic. Cultură şi civilizatie la Dunărea de Jos 19: 26-42.

in print. The Transition from the Mesolithic to the Neolithic between Western Anatolia and the Lower Danube: Evidence from Burial Customs. In A. Reingruber, Z. Tsirtsoni and P. Nedelcheva (eds.), Going West? The Dissemination of Neolithic Innovations between Bosporus and the Carpathians. Proceedings of the EAA Conference, Istanbul 2014. EAA Monograph Series: Themes in Contemporary Archaeology. Taylor \& Francis Group, Abingdon-on-Thames. In print.

Mantu C. 1999-2000. Relative and absolute chronology of the Romanian Neolithic. Analele Banatului 7-8: 75-105.

Marinescu-Bîlcu S. 1981. În legătură cu câteva opinii ale unor cercetători străini asupra neo-eneoliticului românesc. Pontica 14: 39-46.

Markevich V. I. 1974. Bugo-dnestrovskaja kul'tura na teritorii Moldavii. Ştiinţa. Chişinău. 
Mayewski P. A., Rohling E. E. and 14 co-authors. 2004. Holocene climate variability. Quaternary Research 62: 243255.

Milojčić V. 1944. Das ältere Neolithikum in Serbien. Dissertation. Philosophische Fakultät der Universität Wien. Wien.

1949. Chronologie der jüngeren Steinzeit Mittel- und Südosteuropas. Mann. Berlin.

Nestor I. 1951. Cultura ceramicii lineare în Moldova (pe baza săpăturilor arheologice de la Glăvăneștii Vechi, Iaşi). Studii şi Cercetări de Istorie Veche şi Arheologie 2(2): 17-26.

Nikolov V. in print. Thrace, post-6000 BC. In A. Reingruber, Z. Tsirtsoni and P. Nedelcheva (eds.), Going West? The Dissemination of Neolithic Innovations between Bosporus and the Carpathians. Proceedings of the EAA Conference, Istanbul 2014. EAA Monograph Series: Themes in Contemporary Archaeology. Taylor \& Francis Group, Abingdon-on-Thames. In print.

Petrescu-Dîmboviţa M. 1958. Contributions au probleme de la culture Criaaa en Moldavie. Acta Archaeologica Academiae Scientiarum Hungaricae 9: 53-68.

Popuşoi E. 1983. Săpăturile arheologice de la Trestiana, com. Griviţa (jud. Vaslui). Materiale şi Cercetări Arheologice 15: 28-36.

Reingruber A. 2008. Die Argissa Magula. Das frühe und das beginnende Neolithikum im Lichte transägäischer Beziehungen. Die deutschen Ausgrabungen auf der Argissa Magula II. Beiträge zur Ur- und frühgeschichtlichen Archäologie des Mittelmeerraums 35. Habelt. Bonn.

2015. Preceramic, Aceramic or Early Ceramic? The radiocarbon dated beginning of the Neolithic in the Aegean. Documenta Praehistorica 42: 147-158.

in print a. The Beginning of the Neolithic Way of Life in the Eastern Lower Danube Area: A View from the North In A. Reingruber, Z. Tsirtsoni and P. Nedelcheva (eds.), Going West? The Dissemination of Neolithic Innovations between Bosporus and the Carpathians. Proceedings of the EAA Conference, Istanbul 2014. EAA Monograph Series: Themes in Contemporary Archaeology. Taylor \& Francis Group, Abingdon-on-Thames. In print.

in print b. Coastal and Riverine Thrace during the Mesolithic and the Neolithic Period. In K. Bacvarov, R. Gleser (eds.), Southeast Europe and Anatolia in prehistory: essays in honor of Vassil Nikolov on his 65th anniversary. Universitätsforschungen zur Prähistorischen Archäologie Habelt. Bonn.
Reingruber A., Thissen L. 2005. ${ }^{14} \mathrm{C}$ database for the Aegean Catchment (Eastern Greece, Southern Balkans and Western Turkey) 10.000-5500 cal BC. In C. Lichter (ed.), How did farming reach Europe? Anatolian-European Relations from the Second Half of the $7^{\text {th }}$ through the First Half of the $6^{\text {th }}$ Millennium cal BC. Proceedings of the International Workshop Istanbul, 20-22 May 2004. BYZAS 2 Veroffentlichungen des Deutsches Archaeologischen Instituts Istanbul. Ege Yayınları. Istanbul: 295327.

2016. The 14SEA Project: A ${ }^{14} \mathrm{C}$ database for Southeast Europe and Anatolia (10,000-30,000 cal BC). http:// www.14sea.org/ Last accessed 28.11.2016.

Reingruber A., Tsirtsoni Z. and Nedelcheva P. (eds.) in print. Going West? The Dissemination of Neolithic Innovations between Bosporus and the Carpathians. Proceedings of the EAA Conference, Istanbul 2014. EAA Monograph Series: Themes in Contemporary Archaeology. Taylor \& Francis Group, Abingdon-on-Thames. In print.

Sanders E. M. 1923. The New Rumanian State: Regions and Resources. Geographical Review 13 (3): 377-397.

Schachermeyr F. 1955. Die ältesten Kulturen Griechenlands. Kohlhammer. Stuttgart.

Schier W. 1996. The Relative and Absolute Chronology of Vinča: New Evidence from the Type Site. In F. Draşovean (ed.), The Vinča Culture, its Role and Cultural Connections. International Symposion 1995. Mirton. Timişoara: 141-162.

Srejović D. 1988. The Neolithic of Serbia: archaeological research 1948-1988. The University of Belgrade. Faculty of Philosophy. Centre for Archaeological Research. Belgrade.

Stefanova T. 1996. Comparative Analysis of Pottery from the "Monochrome Early Neolithic Horizon" and "Karanovo I Horizon" and the Problems of the Neolithization of Bulgaria. Poročilo o raziskovanju paleolika, neolitika in eneolitika v Sloveniji 23: 15-38.

Stojanovski, D., Nacev T. and Arzarello M. 2014. Pottery typology and the monochrome Neolithic phase in the Republic of Macedonia. In W. Schier, F. Draşovean (eds.), The Neolithic and Eneolithic in Southeast Europe. New approaches to dating and cultural dynamics in the $6^{\text {th }}$ to $4^{\text {th }}$ millennium BC. Prähistorische Archäologie in Südosteuropa 28. Verlag Marie Leidorf. Rahden/Westf.: 9-27.

Szécsényi-Nagy A. and 27 co-authors. 2015. Tracing the genetic origin of Europe's first farmers reveals insights into their social organization. Proceedings of the Royal Society B 282: http://dx.doi.org/10.1098/rspb.2015.0339 
Thissen L. in print. The Beginning of the Neolithic Way of Life in the Eastern Lower Danube Area: A View from the North. In A. Reingruber, Z. Tsirtsoni and P. Nedelcheva (eds.), Going West? The Dissemination of Neolithic Innovations between Bosporus and the Carpathians. Proceedings of the EAA Conference, Istanbul 2014. EAA Monograph Series: Themes in Contemporary Archaeology. Taylor \& Francis Group, Abingdon-on-Thames. In print.

Thissen L., Reingruber A. in print. Appendix: $14 \mathrm{C}$ Database for Southeast Europe and Adjacent Areas (6600-5000 cal BC). In A. Reingruber, Z. Tsirtsoni and P. Nedelcheva (eds.), Going West? The Dissemination of Neolithic Innovations between Bosporus and the Carpathians. Proceedings of the EAA Conference, Istanbul 2014. EAA Monograph Series: Themes in Contemporary Archaeology. Taylor \& Francis Group, Abingdon-on-Thames. In print.

Todorova H. 2003. Neue Angaben zur Neolithisierung der Balkanhalbinsel. In E. Jerem, P. Raczky (eds.), Morgenrot der Kulturen. Frühe Etappen der Menschheitsgeschichte in Mittel- und Südosteuropa. Festschrift für Nándor Kalicz zum 75. Geburtstag. Archaeolingua Alapítvány. Budapest: 83-88.

Tóth M., Magyari E. K., Buczkó K., Braun M., Panagiotopoulos K. and Heiri 0. 2015. Chironomid-inferred Holocene temperature changes in the South Carpathians (Romania). The Holocene 25(4): 569-582.

Tölgyesi C., Bátori Z., Erdős L., Gallé R. and Körmöczi L. 2015. Plant diversity patterns of a Hungarian steppe-wetland mosaic in relation to grazing regime and land use history. Tuexenia 35: 399-416.

Ursulescu N. 1984. Evolutia culturii Starčevo-Criş pe teritoriul Moldovei. Muzeul Județean Suceava. Suceava.
Ursulescu N., Dergacev V. 1991. Influences de type Vinča dans le néolithique ancien de Moldavie. Banatica 11: 156-172.

Vajsov I. 2002. Early monochrome Neolithic in Bulgaria. In Abstract book to the 9th Neolithic Seminar: The Neolithization of Eurasia - Reflections in Archaeology and Archaeogenetics. Ljubljana, 28 November - 1 December 2002. http://arheologija.ff.uni-lj.si/seminars/a9.html (last accessed 9.12.2015).

Voinea V. 2010. Funeral rites in the Hamangia culture: animal sacrifice. Sprawozdania Archaeologiczne 62: 6591.

Wechler K.P. 2001. Studien zum Neolithikum der osteuropäischen Steppe. Archäologie in Eurasien 12. Verlag Philipp von Zabern. Mainz.

Weller 0., Dumitroaia Gh. 2005. The earliest salt production in the world: An early Neolithic exploitation in Poiana Slatinei-Lunca, Romania. Antiquity 79(306): Project Gallery. http://www.antiquity.ac.uk/projgall/weller/

Weninger B. and Harper Th. 2015. The Geographic Corridor for Rapid Climate Change in Southeast Europe and Ukraine. In S. Hansen, P. Ráczky, A. Anders and A. Reingruber (eds.), Neolithic and Copper Age between the Carpathians and the Aegean Sea. Chronologies and Technologies from the $6^{\text {th }}$ to the $4^{\text {th }}$ Millennium BCE. Archäologie in Eurasien 31. Habelt-Verlag. Bonn: 475-505.

Wotzka H.-P. 2014. Kulturbegriff. In D. Mölders, S. Wolfram (eds.), Schlüsselbegriffe der Prähistorischen Archäologie. Tübinger Archäologische Taschenbücher. Waxmann. Münster, New York: 139-144. 
